\section{International Geological Congress}

THE nineteenth session of the Intemational Geological Congress will be held in Algiers during September 8-15. Among the subjects for discussion are the subdivision and correlation of the PreCambrian rocks; the Palæozoic strata of North Africa; the mechanics of rock-deformation; submarine topography and sedimentation; fossil man; the origin of vein-rocks; modern and ancient deserts ; the hydrogeology of arid and sub-arid regions; applied geophysics; the genesis of iron ores and of phosphate deposits; and the oil-fields of the Mediterranean and Middle East. During the session there will also be meetings of the Association of African Geological Surveys, the International Paleontological Union, and the International Committee for the Study of Clays ; and the Society of Economic Geologists will hold a special reunion. The Council of the Congress will discuss the question of forming an International Union of Geology. Draft statutes for an International Association of Sedimentology will also be considered. An extensive programme of geological excursions has been arranged, lasting in all from August 24 to October 28. It includes two series of long excursions through Tunisia, Algeria and Morocco-one series before and one immediately after the sessional meetings; a series of short excursions based on Algiers during the period of the Session; and a fourth series to French West Africa in October. Full details can be obtained from the Secrétaire-Général du Comité d'Organisation du $19^{\mathrm{e}}$ Congrès Géologique International, Faculté des Sciences, Alger, Algérie.

\section{Faraday Society General Discussions in Cambridge and Toronto}

The Faraday Society is holding two General Discussions, one on "The Physical Chemistry of Proteins", in the Department of Zoology, University of Cambridge, during August 6-8, and the other on "The Reactivity of Free Radicals", in the University of Toronto, Canada, during September 8-9. The Cambridge meeting will commence with the sixth Spiers Memorial Lecture, given by Dr. J. T. Edsall, of Harvard University. The programme will then be divided into the following five sessions : experimental techniques, proteins of low molecular weight, systems of high molecular weight, protein interactions, and conjugated proteins (nucleo- and muco-proteins). Twenty-four papers have been arranged for the meeting, advance proofs of which will be circulated by about July 16 ; these papers will be taken as read, and authors will be permitted to speak for five minutes only, before the subject is thrown open for discussion. Application to attend the meeting must be made before July 23. The Discussion in Toronto will open with a general introduction by Dr. E. W. R. Steacie, president of the National Research Council, Ottawa. Twenty-three papers will be presented, and the programme will be in two parts : reactions in the gas phase, and reactions in the liquid phase. Further information on the two Discussions can be obtained from the Secretary of the Faraday Society, 6 Gray's Inn Square, London, W.C.1.

\section{Biology and Productivity of Hot and Cold Deserts}

THE Institute of Biology is organizing a symposium on "The Biology and Productivity of Hot and Cold Deserts", which will be held at the Royal Institution, Albemarle Street, London, W.1, during September 25-27. The symposium will be opened by Dr. Edward
Hindle, and twenty-nine papers will be presented. There will be six sessions as follows: climate and physical environment; plant ecology ; entomology and ecology; economic aspects; and mammalian physiology and ecology (two sessions). Further information can be obtained from the Secretary of the Institute, Tavistock House South, Tavistock Square, London, W.C.I.

\section{Electronics Symposium and Exhibition in London}

THE Electrical and Electronics Section of the Scientific Instrument Manufacturers' Association is holding its fourth Symposium and Exhibition in the Examination Hall, Queen Square, London, W.C.1, during September 2-5. As in previous years, the Symposium will consist of a series of technical papers read by specialist scientific workers and engineers, with an open discussion on instrument users' problems. There will also be a comprehensive display of tho latest types of British scientific and electronic instruments, most of which will be shown in operation during the period of the Exhibition. Entrance to the Exhibition is by presentation of a trade card. For the Symposium a ticket of admission is necessary (covering also the Exhibition), obtainable from the Secretary of the Scientific Instrument Manufacturers' Association, 20 Queen Anne Street, London, W.1.

\section{Research on Safety in Mines}

TнE Seventh International Conference of Directors of Safety in Mines Research is being held at Buxton during July 7-12 at the Safety in Mines Research Establishment of the Ministry of Fuel and Power. Thirty-eight papers have been submitted for discussion from Austria, Belgium, Canada, France, Germany, Great Britain, Holland, Poland and the United States. Other countries represented include India, Nigeria, Turkey and Southern Rhodesia. The agenda is restricted to the discussion of scientific and technical research on problems of safety; health problems, including pneumoconiosis of coal miners, administrative and legal problems will not be discussed. Copies of papers submitted to the Conference may be obtained after July 12 from the Safety in Mines Research Establishment, Portobello Street, Sheffield.

\section{Royal Meteorological Society : Officers}

THE following have been elected officers of the Royal Meteorological Society for the year 1952-53: President, Sir Charles Normand ; Vice-Presidents, Sir David Brunt, Wing-Commander R. M. Poulter, Sir Robert Watson-Watt and W. M. Witchell ; VicePresident for Canada, A. Thomson; Vice-President for Scotland, E. G. Dymond ; Secretaries, Prof. P. A. Sheppard and R. G. Veryard (49 Cromwell Road, London, S.W.7) ; Treasurer, Dr. J. S. Farquharson ; and Editor, Prof. P. A. Sheppard.

\section{Standardized Nomenclature for Inbred Strains of Mice}

AN international committee consisting of $T$. C. Carter, L. C. Dunn, D. S. Falconer, H. Grüneberg, W. E. Heston and G. D. Snell has been studying the question of a standardized system of nomenclature for inbred strains and sub-strains of mice. A set of rules for naming such strains has been prepared, and has now been published (Cancer Research, 12, No. 8). A fairly complete list of existing inbred mouse strains 